\title{
Systemic evaluation on ischemia and reperfusion injury of splanchnic organs in rats ${ }^{1}$
}

\author{
Alterações sistêmicas na isquemia e reperfusão de órgãos esplâncnicos em ratos
}

\author{
Nereide Freire Cerqueira', Carlos Alberto HussniI", Winston Bonetti Yoshida ${ }^{I I I}$, Carlos Roberto Padovani ${ }^{\text {IV }}$ \\ ${ }^{\text {I }} \mathrm{PhD}$, Department of Veterinary Surgery and Anesthesiology, School of Veterinary Medicine and Animal Science (FMVZ), UNESP, Brazil. \\ ${ }^{\text {II }}$ Assistant Professor, Department of Veterinary Surgery and Anesthesiology, FMVZ, UNESP, Brazil. \\ ${ }^{\text {III }}$ Assistant Professor, Department of Surgery and Orthopedics, Botucatu School of Medicine, UNESP, Brazil. \\ ${ }^{\text {Iv }}$ Full Professor, Department of Biostatistics, Institute of Biosciences, UNESP, Brazil.
}

\begin{abstract}
Purpose: To evaluate hemodynamic and systemic changes during and after splanchnic ischemia and reperfusion (I/R). Methods: Rats were divided into two groups: a) control: animals submitted to surgery, but not to I/R, treated with saline (5 ml/ $/ \mathrm{kg} / \mathrm{h}$ ) for $150 \mathrm{~min}$; b) group I/R: animals continuously infused with saline, and submitted to occlusion of the celiac trunk, superior mesenteric artery (SMA), and inferior mesenteric artery for $30 \mathrm{~min}$, followed by a 120-min reperfusion. Mean arterial blood pressure (MABP), venous pressure, aortic and SMA blood flow, heart rate, esophageal temperature and hematocrit were evaluated. Results: During reperfusion in I/R groups, there was a progressive decrease in MABP, aortic blood flow, SMA blood flow, heart rate and esophageal temperature; vein pressure and hematocrit remained unchanged during the experiment. Conclusion: The model of ischemia used causes systemic changes, which are evidenced by hypotension, decrease in mesenteric blood flow, heart rate and esophageal temperature.
\end{abstract}

Key words: Ischemia. Reperfusion. Intestine, Small. Shock. Rats.

\section{RESUMO}

Objetivo: Avaliar as alterações hemodinâmicas e sistêmicas decorrentes de isquemia e reperfusão (I/R) esplâncnica em ratos. Métodos: Vinte ratos foram divididos em dois grupos: grupo controle: os animais foram submetidos à cirurgia, mas não a I/R e foram tratados com solução fisiológica $(5 \mathrm{ml} / \mathrm{kg} / \mathrm{h})$ por 150 minutos; grupo I/R: os animais foram submetidos à administração contínua de solução fisiológica e à oclusão do tronco celíaco, artéria mesentérica superior e artéria mesentérica inferior por 30 minutos, seguidos por 120 minutos de reperfusão. Avaliou-se a pressão arterial média, pressão venosa, fluxo sangüíneo na aorta e na artéria mesentérica superior, freqüência cardíaca, temperatura esofágica e hematócrito. Resultados: Durante a reperfusão, no grupo I/R, houve uma diminuição progressiva da pressão arterial média, fluxo sangüíneo na aorta e artéria mesentérica superior, freqüência cardíaca e temperatura esofágica; pressão venosa e hematócrito não sofreram alteração. Conclusão: O modelo de isquemia provocado por oclusão da artéria mesentérica superior, artéria mesentérica inferior e tronco celíaco por 30 minutos seguidos por 120 minutos de reperfusão provoca alterações sistêmicas evidenciadas por hipotensão, diminuição do fluxo sangüíneo mesentérico, da freqüência cardíaca e da temperatura esofágica.

Descritores: Isquemia. Reperfusão. Intestino Delgado. Choque. Ratos.

${ }^{1}$ Research performed at Laboratory of Experimental Surgery, Sao Paulo State University (UNESP), Botucatu-SP, Brazil.

\section{Introduction}

Ischemia and reperfusion $(\mathrm{I} / \mathrm{R})$ of mesenteric vessels is usually accompanied by acute vascular insufficiency and early stages of multiorgan failure, conditions associated with morbidity and mortality ${ }^{1}$. This syndrome is of relevance in situations where there is an interruption of blood supply to the gut, as in vascular surgery, or in the construction of intestinal grafts or cases of shock, sepsis, and trauma ${ }^{2}$.

The celiac and the superior mesenteric arteries supply approximately $90 \%$ of the blood flow to the liver, pancreas and intestine. Thus, the occlusion of these vessels results in severe ischemia in these organs ${ }^{3}$. Occlusion and reperfusion of the splanchnic arteries cause circulatory shock, especially due to an increase in vascular permeability, activation and adherence of polymorphonuclear neutrophils, release of proinflammatory substances, formation of reactive oxygen species (ROS) and reactive nitrogen species ${ }^{4,5}$. Mucosal injury, bacterial translocation and activation of inflammatory responses occur in the small intestine $^{6}$, besides hydroelectrolytic disorders and acid-base imbalance in remote organs ${ }^{7}$.

Splanchnic artery occlusion shock (SAO shock) is an experimental type of circulatory shock that results from ischemia and reperfusion of the splanchnic region. This model of shock is characterized by a decrease in blood pressure and leukopenia, as well as by disturbances in reticulo-endothelial system activity, increased macrophage and plasma levels of thromboxane B2, and elevated plasma levels of the platelet-activating factor. Other SAO 
characteristics include local splanchnic release of lysosomal hydrolases, enhanced proteolysis, hemoconcentration, intestinal injury, and production of cardiotoxic substances ${ }^{8}$. SAO shock hemodynamics knowledge come from scattered information gathered from several studies in which only small sets of hemodynamic parameters were determined. Were not able to find a study with a whole set of hemodynamic parameters determined in a sole experimental study.

The purpose of this study was to evaluate hemodynamic parameters such as mean arterial blood pressure (MABP), vein pressure, aortic and SMA blood flow, as well as esophageal temperature and hematocrit in the conditions associated with circulatory shock in an experimental model of ischemia and reperfusion of the celiac trunk, superior mesenteric artery (SMA) and inferior mesenteric artery in rats. This study is part of a larger study concerning the effects of different drugs on injuries caused by ischemia and reperfusion of splanchnic organs in rats.

\section{Methods}

Twenty male Wistar rats 60 to 65 days old and weighing $318.35 \pm 29.26 \mathrm{~g}$ were used. Experimental procedures were approved by the local Ethics Committee.

The animals were anesthetized with sodium pentobarbital (30 mg/kg, intraperitoneally). A median longitudinal incision was made on the anterior face of the neck, and the left carotid artery and right jugular vein were cannulated to record arterial and venous blood pressure. The catheter was connected to a pressure transducer of a data acquisition system (MP110, Biopac Systems Inc., Goleta, CA. USA). The temperature was electronically measured every 10 minutes by a sensor placed in the esophagus of the animal and connected to the same data acquisition system. After median laparotomy, blood-flow sensors (Transonic Systems
Inc., Ithaca, NY. USA) were placed in the suprarenal abdominal aorta and in the superior mesenteric artery. Blood samples were collected from the jugular vein before ischemia and after reperfusion to determine hematocrit values. Hemodynamic parameters (mean arterial blood pressure, blood flow and heart rate) were evaluated continuously throughout the experiment.

After a 30-min stabilization period, the animals were divided into two groups: control and I/R. Control animals underwent sham $\mathrm{I} / \mathrm{R}$ and were treated with saline solution ( $5 \mathrm{ml} / \mathrm{kg} / \mathrm{h}$ via jugular vein) for $150 \mathrm{~min}$. In the I/R group, the celiac trunk and the superior and inferior mesenteric arteries were sequentially occluded with a bulldog clamp (Vascu-Statt ${ }^{\circledR}$ ) for $30 \mathrm{~min}$ followed by 120 minutes of reperfusion, and were treated with saline solution (same dose and route).

Statistical calculations were done at 30,60 and 180 minutes of the study. The hemodynamic parameters, esophageal temperature and hematocrit values were evaluated by variance analysis for repeat measures with two independent factors ${ }^{9}$. The level of significance was established at $5 \%$.

\section{Results}

Twenty-four rats were included for this study, but four of the I/R group died during reperfusion and were replaced. Animals that underwent $\mathrm{I} / \mathrm{R}$ had a significant elevation of mean arterial blood pressure (MABP) shortly after arterial occlusion, which then progressively felt but did not return to basal values up to 30 minutes of ischemia Shortly after the vascular clamps were released, MABP felt substantially for about 20 minutes. MABP was significantly lower in I/R group than in the control group along the reperfusion (Figure 1). However, no significant changes in median vein pressure were observed during this period (Figure 2).

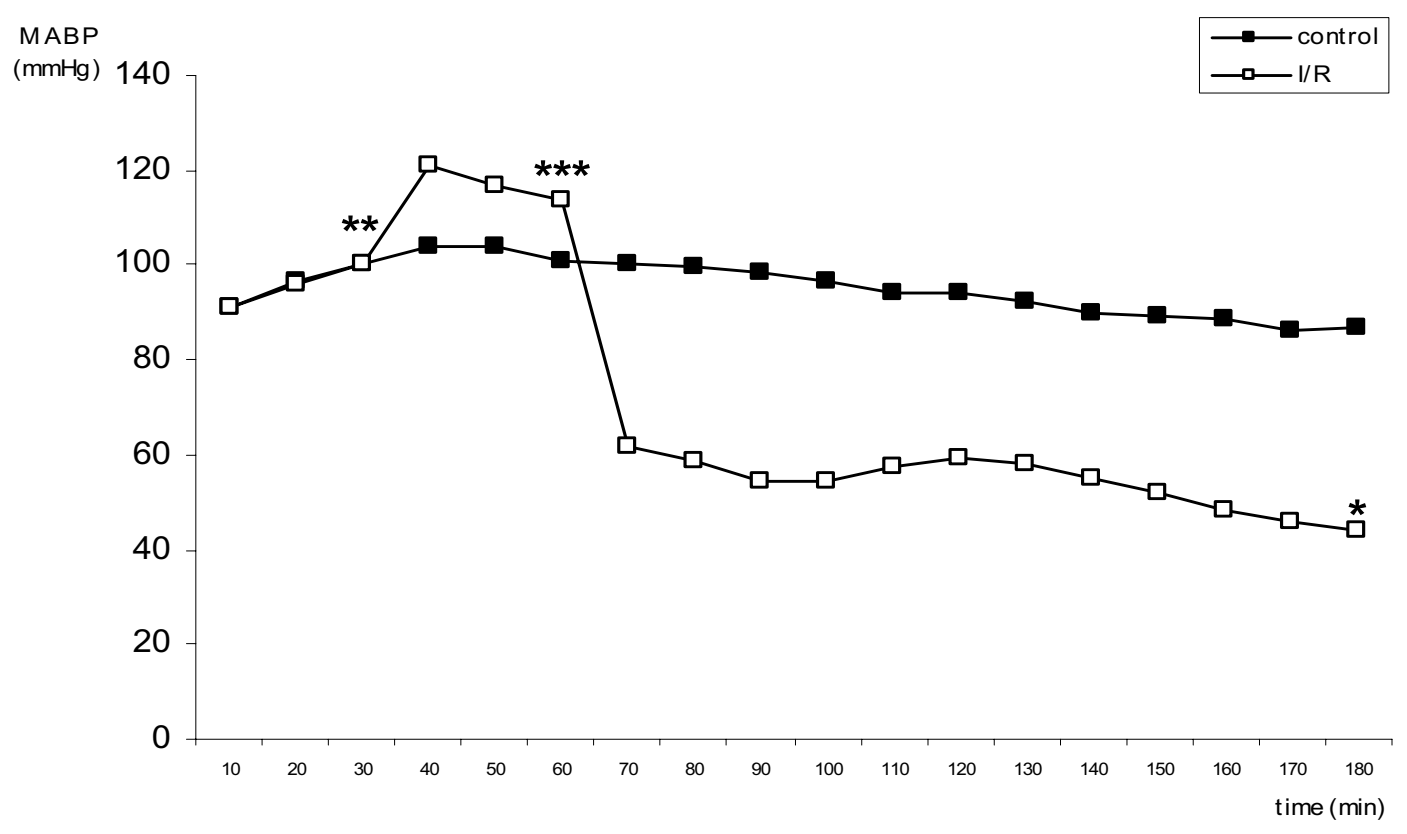

FIGURE 1 - Mean arterial blood pressure $(\mathrm{mmHg})$ along time. Asterisk indicates significant differences according experimental time in $\mathrm{I} / \mathrm{R}$ group $(\mathrm{p}<0.05)$ 


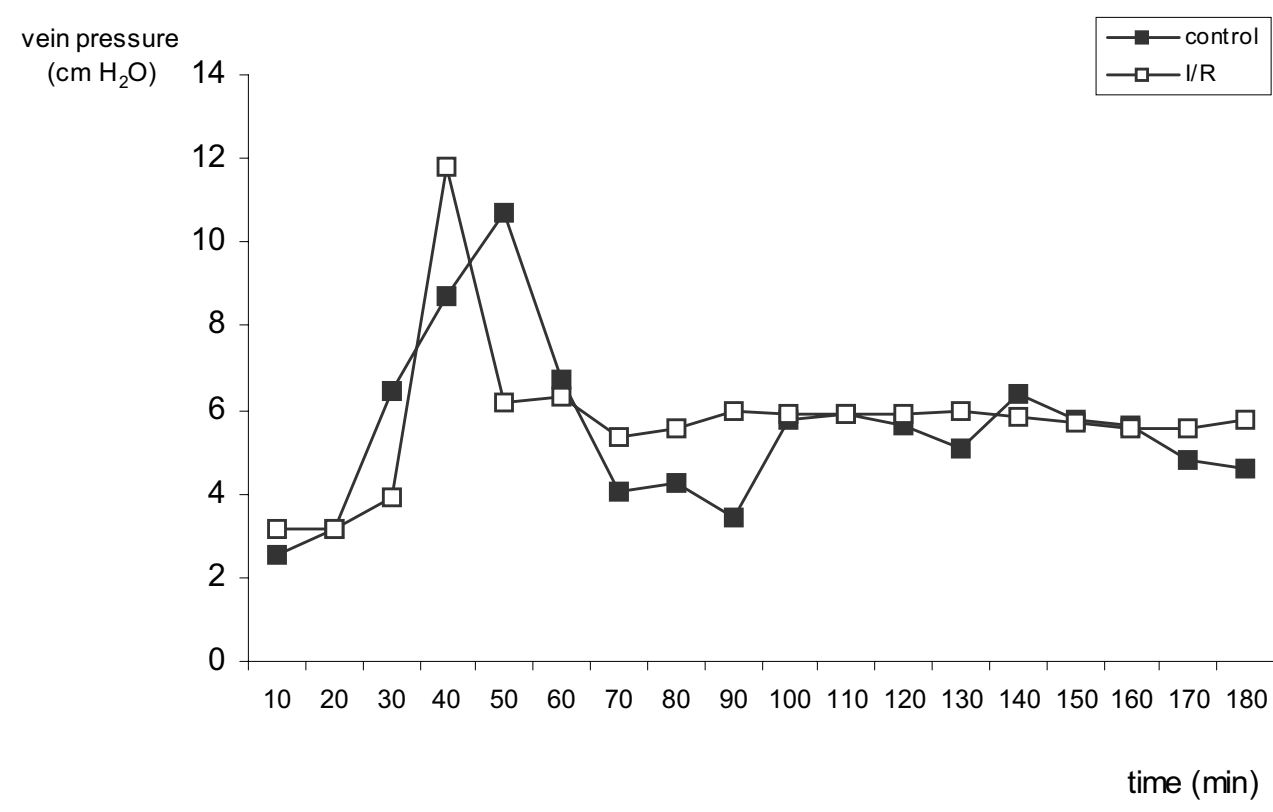

FIGURE 2 - Median vein pressure $(\mathrm{cmH} 2 \mathrm{O})$ along time $(\mathrm{p}<0.05)$

Median aortic blood flow increased in the control group after 30 minutes of infusion with saline solution. After 30 minutes of ischemia, animals in the I/R group had a significant decrease in median aortic blood flow, which fell progressively until the end of the reperfusion period (Figure 3 ).

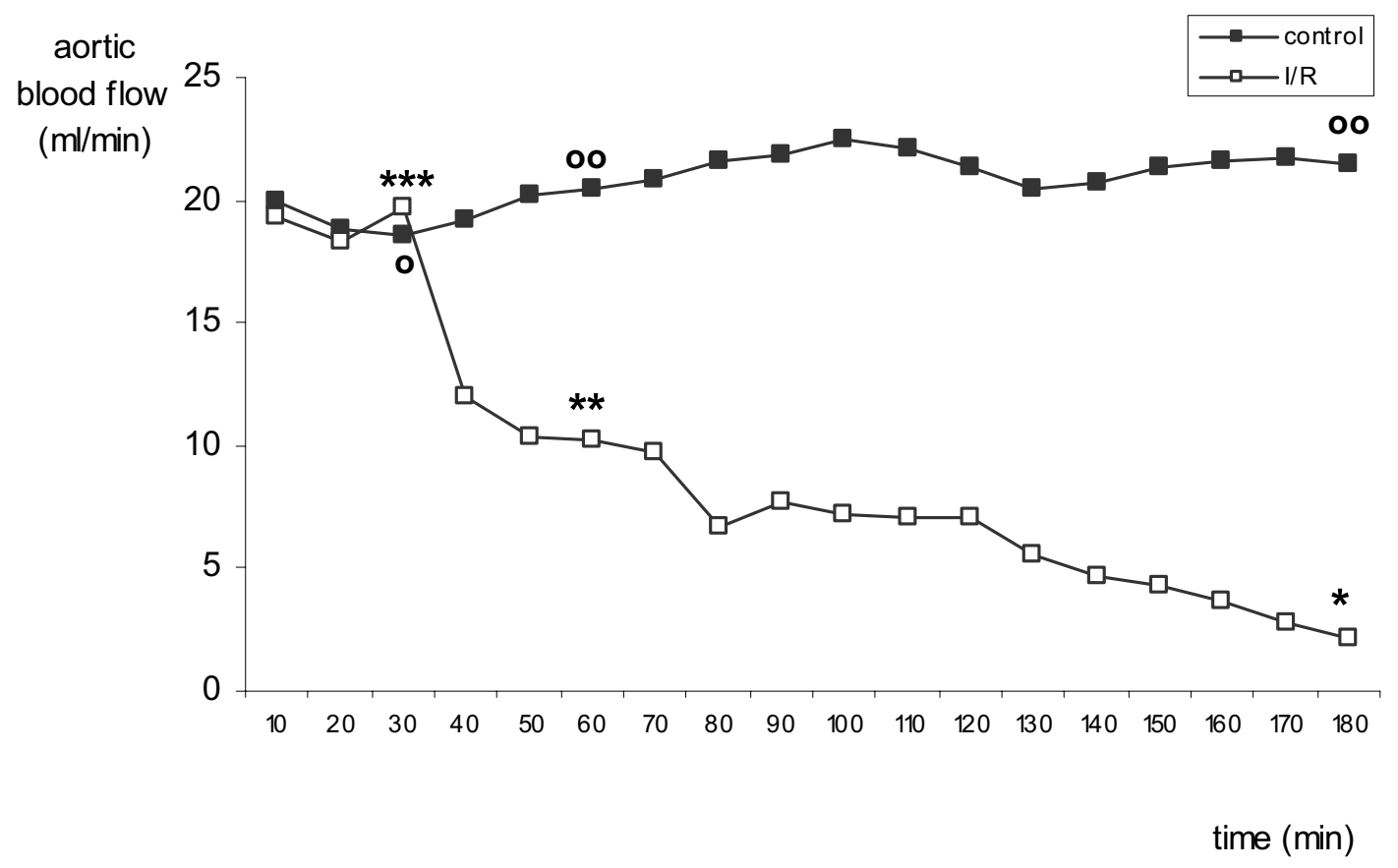

FIGURE 3 - Median aortic blood flow ( $\mathrm{ml} / \mathrm{min}$ ) along time. Asterisk and circle indicate significant differences according experimental time in $\mathrm{I} / \mathrm{R}$ and control groups, respectively $(\mathrm{p}<0.05)$ 
In the control group, median SMA blood flow decreased after 150 minutes of infusion. In the I/R group, median SMA blood flow did not return to basal values after 120 minutes of reperfusion, despite temporary elevation observed following circulation restoration (Figure 4).

Mean heart rate (HR) and esophageal temperature were constant over the experimental period in the control group. In the I/R group, mean HR and esophageal temperature decreased progressively during ischemia and more markedly after reperfusion (Figures 5 and 6).

Mean hematocrit values showed no significant differences in both groups.

\section{Discussion}

Although many models have been developed for the study of intestinal ischemic injury, rats have been the animals most utilized. The collateral mesenteric circulation of the rat is very similar that of the human, which permits extrapolation of much knowledge acquired from rats to the human species ${ }^{10}$. Occlusion of SMA and of the celiac trunk results in an intense degree of ischemia in the intestine, liver and pancreas. Together, they supply approximately $90 \%$ of blood flow in these organs ${ }^{11}$. In the present study, occlusion of SMA, IMA and celiac trunk was realized according to previous studies ${ }^{12}$, with the aim of obtaining an accentuated degree of I/R.

In the present study, MABP increased temporarily and then fell to levels higher than basal MABP at the end of the ischemic period. Macarengo et $a l .{ }^{4}$ observed that MABP significantly increased after occlusion of the celiac trunk, SMA and inferior mesenteric artery, returning to baseline values after 30 minutes. Simonian et al. ${ }^{13}$ reported that the occlusion

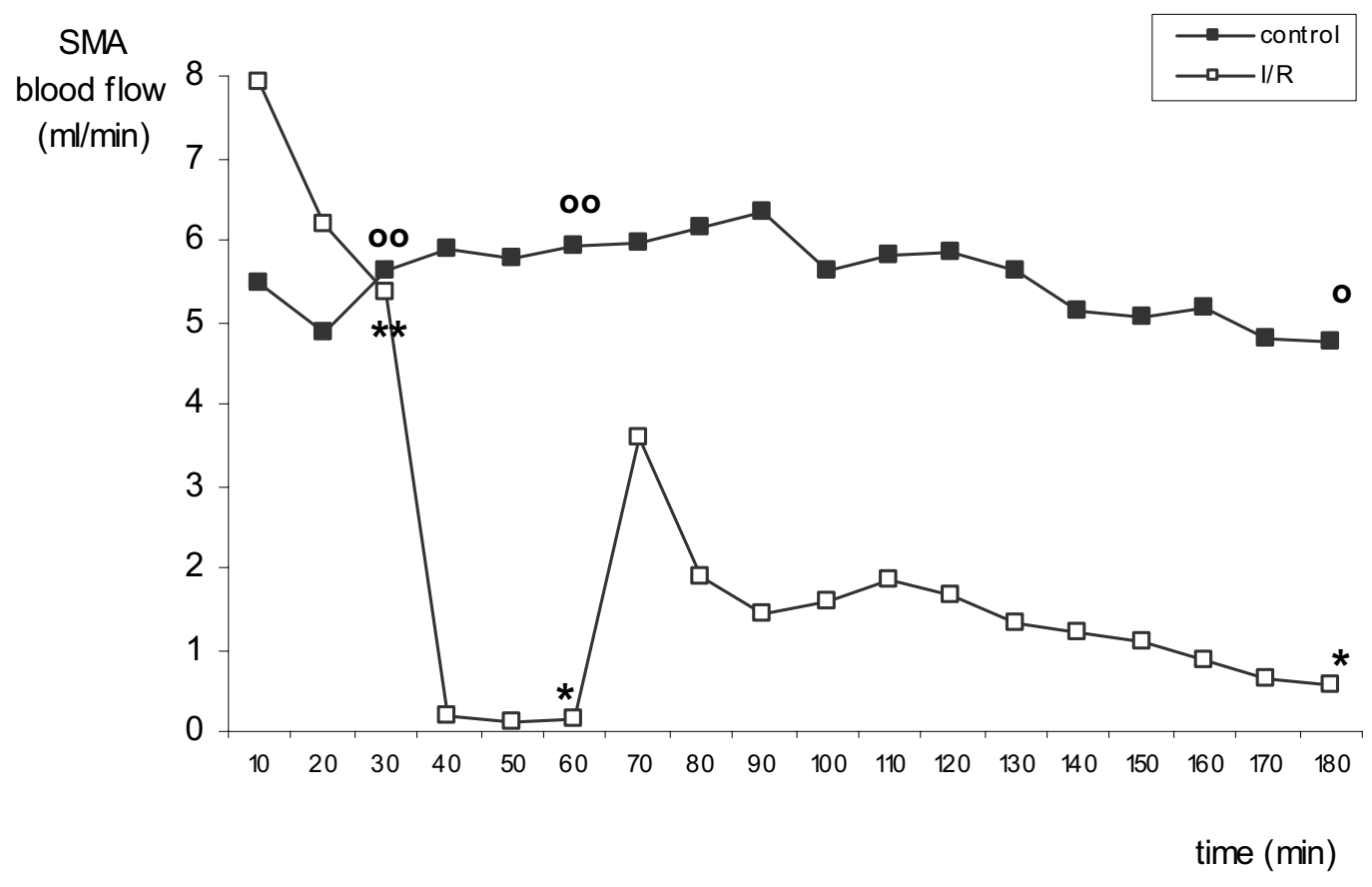

FIGURE 4 - Median superior mesenteric artery blood flow ( $\mathrm{ml} / \mathrm{min})$ along time. Asterisk and circle indicate significant differences according experimental time in $\mathrm{I} / \mathrm{R}$ and control groups, respectively $(\mathrm{p}<0.05)$

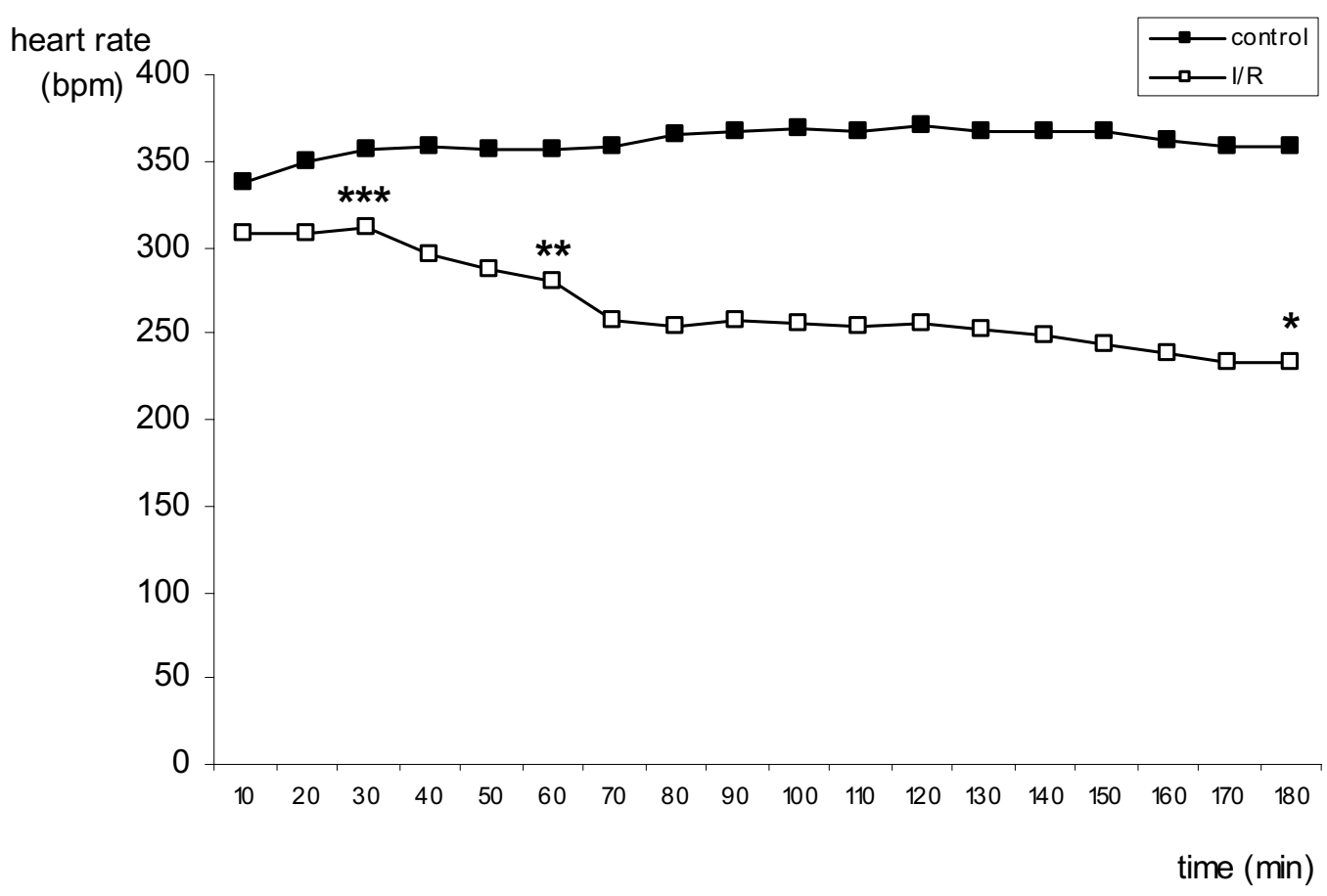

FIGURE 5 - Mean heart rate (bpm) along time. Asterisk indicates significant differences according experimental time in $\mathrm{I} / \mathrm{R}$ group $(\mathrm{p}<0.05)$ 
of the celiac trunk and SMA produced a transient hypertension that normalized over a period of 20 to 35 minutes. Khanna et al. ${ }^{14}$ also observed a marked elevation in MABP following SMA occlusion, with a return to control values within 40 minutes of ischemia. According to Hayward and Lefer ${ }^{11}$, the abrupt increase in systemic arterial blood pressure, induced by reduced splanchnic flow during intestinal ischemia in rats, may be mediated by the baroreceptor input to the medullary vasomotor center in response to reduced splanchnic perfusion. This increased in MABP is transitory and returns to near preocclusion levels by the end of the ischemic period, probably due to transudation of fluid across the microcirculation ${ }^{11}$. On reperfusion of the splanchnic circulation, a marked decrease in MABP has been reported, indicating the occurrence of a severe form of circulatory shock ${ }^{11}$. This reduction in postreperfusion MABP may be primarily mediated by the release of platelet activating factor from the postischemic intestine ${ }^{14,15}$.

No significant change in vein pressure was observed in our study groups, however, the same jugular vein was also used to infusion with saline solution, which may be a methodological limitation and so, this result can not be considered as valid. Ideally, the measurement of the vein pressure and the infusion of substances should be done in different vessels.

In the present study, blood flow in the aorta decreased progressively in I/R group, possibly due to peripheral vasodilatation. No studies dealing with aortic blood flow during mesenteric I/R were found in the literature.

SMA blood flow rapidly increased during the initial 10 minutes of reperfusion. However, it progressively decreased to near zero values by the end of the evaluation period. Byrka-Owczarek et al. ${ }^{16}$ observed that SMA blood flow dropped to $70.5 \%$ of initial values after 3 hours of SMA occlusion and 1 minute of reperfusion, and to $27.3 \%$ of initial values after 30 minutes of reperfusion. According to these authors, restoration of normal blood flow in microcirculation during reperfusion is not always possible. It depends on the duration of ischemia and the no-reflow phenomenon provoked by the adherence of neutrophils to the capillary walls and the microcirculation occlusion ${ }^{17}$. After a prolonged period of vascular occlusion, when perfusion is restored, the blood flow to that organ or tissue stabilizes for several seconds and then diminishes gradually ${ }^{16}$.

Heart rate (HR) was evaluated in other I/R studies ${ }^{18,19}$. Contrary to their findings, the HR of animals in our I/R group did not return to basal values after bradycardia caused by ischemia; heart rate was even lower than at baseline. Differently of our result, Khanna et al. ${ }^{14}$ observed that reperfusion in $\mathrm{I} / \mathrm{R}$ rats induced a decrease in heart rate, gradually reversed during reperfusion and eventually returned to more elevated values than baseline. These authors suggest that, while the initial bradycardia may has been mediated by vagal stimulation or release of a myocardial depressant factor, development of tachycardia may has been a response to decrease of MABP or a response to hypervolemia due to I/R.

Esophageal temperature decreased continuously after mesenteric I/R, but animals in the control group had no significant changes in temperature. Our study was conducted at room temperature and vasomotor responses would be less variable if was conducted under controlled temperature. Hazinedaroglu et al..$^{20}$, for example, maintained the body temperature of rats that underwent mesenteric $\mathrm{I} / \mathrm{R}$ constantly at $35^{\circ} \mathrm{C}$, and Illyes and Hamar $^{21}$, at $37^{\circ} \mathrm{C}$.

Horton and Walker ${ }^{18}$ and Horton and White ${ }^{19}$ reported no change in hematocrit values following $\mathrm{I} / \mathrm{R}$ in rats, perhaps because volemia was maintained. However, another study demonstrated increased in hematocrit values after $\mathrm{I} / \mathrm{R}^{22}$.

Thus, the model used herein, in which ischemia is induced by the occlusion of the superior mesenteric artery, inferior mesenteric artery, and celiac trunk for 30 minutes, followed by a 120 -min reperfusion with the continuous infusion of saline solution, results in severe systemic alterations evidenced by hypotension, decrease in blood flow, heart rate and esophageal temperature, characterizing an splanchnic artery occlusion shock (SAO shock). To our knowledge, hemodynamic parameters altogether, associated with esophageal temperature and hematocrit have not yet been determined altogether in other studies after mesenteric I/R. Their knowledge may be important to the understanding of the pathophysiology of this important syndrome and may be a fundamental tool for new treatment testing. 


\section{Conclusion}

The model of ischemia used causes systemic changes, which are evidenced by hypotension, decrease in mesenteric blood flow, heart rate and esophageal temperature.

\section{References}

1. Berlanga J, Prats P, Remires D, Gonzales R, Lopez-Saura P, Aguiar J, Ojeda M, Boyle JJ, Fitzgerald AJ, Playford RJ. Prophylactic use of epidermal growth factor reduces ischemia/reperfusion intestinal damage. Am J Pathol. 2002;161:373-9.

2. Kong SE, Blennerhassett LR, Heel KA, McCauley RD, Hall JC. Ischaemia-reperfusion injury to the intestine. Aust N Z J Surg. 1998;68(8):554-61.

3. Lillehei RC. The intestinal factor in irreversible hemorrhagic shock. Surgery 1957;42:1043-7.

4. Macarengo RSS, Takahagi RU, Bardella LC, Sequeira JL, Yoshida WB. Estudo da ação do extrato de Gingko biloba e amido hidroxietílico hipertônico na atenuação de alterações decorrentes de isquemia e reperfusão de órgãos esplâncnicos em ratos. Acta Cir Bras. 2001;16:139-45.

5. Cuzzocrea S, Chatterjee P, Mazzon E, Dugo L, De Sarro A, Van de Loo FAJ, Caputi AP, Thiemermann C. Role of induced nitric oxide in the initiation of the inflammatory response after postischemic injury. Shock. 2002;18:169-76.

6. João AS, Alencar SSS, Medeiros AC, Diniz SOF, Cardoso VN, Brandt CT. Translocation of $99 \mathrm{mTC}$ labelled bacteria after intestinal ischemia and reperfusion. Acta Cir Bras. 2004;19(4):328-33.

7. Turnage RH, Guice KS, Oldham KT. Endotoxemia and remote organ injury following intestinal reperfusion. J Surg Res. 1994;56:571-8.

8. Cuzzocrea S, Mazzon E, Costantino G, Serraino I, De Sarro A, Caputi AP. Effects of n-acetylcysteine in a rat model of ischemia and reperfusion injury. Cardiovasc Res. 2000;47:537-48.

9. Johnson RA, Wichern DW. Applied multivariate statistical analysis. 4ed. New Jersey: Prentice-Hall; 1998.

10. Ribeiro ME, Yoshida WB. Lesões intestinais decorrentes de isquemia e reperfusão: fisiopatologia e modelos experimentais. J Vasc Br. 2005;4(2):183-94.
11. Hayward R, Lefer A.M. Time course of endothelial-neutrophil interaction in splanchnic artery ischemia-reperfusion. Am J Physiol. 1998;275:H2080-6.

12. Yoshida WB, Alasio T, Mazziotta R, Qin F, Kashani M, Lee S, Dardik $H$. Effect of $\alpha$-tocopherol, taurine and selenium on the attenuation of ischemia/reperfusion injury of splanchnic organs. Cardiovasc Surg. 1998;6:178-87.

13. Simonian GT, Dardik G, Hallac D, Mazziotta R, Ibrahim I, Stahl R. Hemodynamic and histopathologic effects of hydroxyethil starch and superoxide dismutase following splanchnic arterial occlusion in a murine model. Vasc Surg. 1997;31:645-56.

14. Khanna A, Rossman JE, Fung HL, Caty MG. Intestinal and hemodynamic impairment following mesenteric ischemia/reperfusion. J Surg Res. 2001;99:114-9.

15. Kozar RA, Holcomb JB, Hassoun HT, Macaitis J, Desoignie R, Moore FA. Superior mesenteric artery occlusion models shock-induced gut ischemia-reperfusion. J Surg Res. 2004;116:145-50.

16. Byrka-Owczarek K, Steplewska-Mazur K, Krason M, Bohosiewicz J, Koszutski T, Wojtynek G. The evaluation of the protective action of antioxidants on small intestine of rabbits experimentally injured by ischemia and reperfusion. J Pediatr Surg. 2004;39:1226-9.

17. Yoshida, WB. Radicais livres na síndrome de isuqmeia e reperfusão. Cir Vasc Angiol. 1996;12:82-95.

18. Horton JW, Walker PB. Oxygen radicals lipid peroxidation and permeability changes after intestinal ischemia and reperfusion. J Appl Physiol. 1993; 74:1515-20.

19. Horton JW, White DJ. Lipid peroxidation contributes to cardiac deficits after ischemia and reperfusion of the small bowel. Am J Physiol. 1993;264:H1686-92.

20. Hazinedaroglu FM, Dulger Kayaoglu, HA Pehlivan, M Serinsoz, E Canbolat, O, Erverdi N. N-acetylcysteine in intestinal reperfusion injury: an experimental study in rats. Anz J Surg. 2004;74:676-8.

21. Illyés G, Mar J. Sequence of morphological alterations in a small intestinal ischaemia/reperfusion model of the anesthetized rat: a light microscopy study. Int J Exp Pathol. 1992;73:161-72.

22. Ulibarrena MA, García-Alonso I, Portugal, V, García-Redondo B, Mendez J. Hemodynamic monitoring in a model of shock induced by intestinal reperfusion in the rat. Rev Esp Enferm Dig. 1998;90:100-4.

Conflict of interest: none Financial source: FAPESP

\section{Correspondence:}

Nereide Freire Cerqueira

Dep Cir Anestesiol Vet

Fac Med Vet Zootec de Botucatu, UNESP

Caixa Postal 560

18618-000 Botucatu - SP Brazil

nereidef@zipmail.com.br

Received: January 14, 2009

Review: March 18, 2009

Accepted: April 16, 2009

\section{How to cite this article}

Cerqueira NF, Hussni CA, Yoshida WB, Padovani CR. Systemic evaluation on ischemia and reperfusion injury of splanchnic organs in rats. Acta Cir Bras. [serial on the Internet] 2009 July-Aug;24(4). Available from URL: http://www.scielo.br/acb 